\title{
PEMBERIAN MAKANAN PRALAKTASI DENGAN KELANGSUNGAN HIDUP BAYI DI INDONESIA (ANALISIS DATA SDKI 2007)
}

\author{
Utami Dewi ${ }^{1}$, Siswanto Agus Wilopo ${ }^{2}$, Tunjung Wibowo ${ }^{3}$
}

\begin{abstract}
Background: It is recommended for a mother to initiate and give early breastfeeding for a newborn as the first breast milk is known to be nutritious and contains antibody. The delay of breastfeeding may stimulate non breast milk-supplementary food to be given. Based on BPS and Macro International data $65 \%$ of infants received pre-lacteal feeds besides breast milk in their three days of life.

Objective: the known relationship between pre-lacteal feeds and infants' survival in Indonesia.

Method: This was an observational study with a cohort retrospective study design by using IDHS data year 2007. Samples were all infants (0-12 months, breastfed after birth) from mothers aged 15-49 years old as many as 2,886 mothers. The independent variable was pre-lacteal feeds after birth and the dependent variable was infants' survival. The analyses used univariable, bivariable, and survival analysis with Kaplan-Meier, Log regression and Cox regression.

Result and Discussion: Bivariable analysis using survival Kaplan-Meier showed that there was a significant relationship between pre-lacteal feeds after birth and infants' survival. The survival of infants who received prelacteal feeds was greater than that of infants who did not receive pre-lacteal feeds (92\%:89\%). Multivariable analysis using Cox regression showed that the survival chance in infants who did not receive pre-lacteal feeds was 0.63 times lower than that in infants who received pre-lacteal feeds (HR 0.63; $\mathrm{Cl} 95 \%=0.42-0.95)$.

Conclusion: Pre-lacteal feeds shows relationship with infant survival. Other factors affecting infant's survival were mother's age $<20$ and $\leq 35$ years, low economic status, and birth assistant with non professional.
\end{abstract}

Keyword: infant's survival, pre-lacteal feeds, infant

\begin{abstract}
ANSTRAK
Latar Belakang : Pemberian Air Susu Ibu (ASI) sejak dini sangat dianjurkan karena ASI yang keluar pertama kali sangat bergizi dan mengandung antibodi. Keterlambatan memulai pemberian ASI menunjukkan bahwa adanya pemberian makanan dan minuman selain ASI. Menurut Data BPS dan Macro International sebesar 65\% bayi yang dilahirkan mendapatkan makanan pralaktasi selain ASI pada tiga hari pertama kehidupan.

Tujuan : Diketahuinya hubungan pemberian makanan pralaktasi terhadap kelangsungan hidup bayi di Indonesia. Metode : Jenis penelitian observasional dengan rancangan cohort retrospectif menggunakan data SDKI 2007. Sampel penelitian adalah semua bayi (berumur 0-12 bulan, menyusu setelah lahir) dari ibu yang berumur 15-49 tahun berjumlah 2.886. Variabel bebas adalah pemberian makanan pralaktasi setelah lahir, variabel terikat kelangsungan hidup bayi. Analisis yang digunakan adalah univariabel, bivariabel dan analisis survival dengan Kaplan- Meier, Log regression dan Cox regression.

Hasil dan Pembahasan: Analisis bivariabel dengan survival Kaplan-Meir didapatkan hubungan yang bermakna antara pemberian makanan pralaktasi setelah lahir dengan kelangsungan hidup bayi, namun kelangsungan hidup lebih tinggi pada bayi yang mendapatkan makanan pralaktasi dibandingkan dengan yang tidak mendapatkan
\end{abstract}

1. Sekolah Tinggi Kesehatan Hangtuah, Pekanbaru

2. Magister Kesehatan Ibu dan Anak-Kesehatan Reproduksi, FK UGM

3. Bagian IImu Kesehatan Anak, Fakultas Kedokteran, UGM 
makanan pralaktasi (92\%:89\%). Analisis multivariabel dengan Cox regresion menunjukkan peluang kelangsungan hidup pada bayi yang tidak mendapatkan makanan pralaktasi sebesar 0,63 kali lebih rendah dibandingkan dengan yang mendapatkan makanan pralaktasi (HR 0,63; Cl 95\%=0,42-0,95).

Kesimpulan : Pemberian makanan pralaktasi berhubungan dengan kelangsungan hidup bayi. Faktor lain yang berpengaruh terhadap kelangsungan hidup bayi adalah umur ibu $<20$ dan $\leq 35$ tahun, sosial ekonomi rendah dan penolong persalinan oleh non nakes

Kata kunci: kelangsungan hidup bayi, pemberian makanan pralaktasi, bayi

\section{PENDAHULUAN}

Tidak dapat dipungkiri bahwa anak merupakan tumpuan harapan masa depan. Kelangsungan hidup anak masih menjadi masalah besar, khususnya di beberapa negara. Ancaman terhadap kelangsungan hidup anak tercermin pada Angka Kematian Bayi (AKB) yang masih tinggi. Sesuai dengan tujuan Millennium Development Goals (MDGs) adalah menurunkan Angka Kematian Balita sebesar dua pertiganya antara tahun 1990 dan 2015 termasuk di dalamnya adalah Angka Kematian Bayi (AKB). Kematian bayi sangat bervariasi di seluruh dunia dan perbedaan kematian hampir 20-29 kali di beberapa negara. Kematian di Sub Sahara Afrika pada tahun 1990 terdapat 180 per 1.000 kelahiran hidup $(\mathrm{KH})$ turun menjadi 175 per $1.000 \mathrm{KH}$ pada tahun 2000, sedangkan di negara industri kematian hanya 9 per $1.000 \mathrm{KH}$ pada tahun 1990 , turun menjadi 6 per 1.000 $\mathrm{KH}$ pada tahun 2000. ${ }^{1,2}$

Angka Kematian Bayi (AKB) di Indonesia telah turun selama periode lima belas tahun dari 54 per $1.000 \mathrm{KH}$ selama periode $1988-1997$ menjadi 44 per $1.000 \mathrm{KH}$ selama periode $1998-2002$ dan menjadi 34 per $1.000 \mathrm{KH}$ selama periode 2003-2007. Walaupun kematian bayi terjadi penurunan namun dibandingkan dengan negara di ASEAN, Indonesia mempunyai angka kematian bayi tertinggi setelah Kamboja, Myanmar dan Laos. ${ }^{3}$

World Health Organization (WHO) memperkirakan kematian pada anak di bawah lima tahun disebabkan 19\% pneumonia, 13\% diare, 9\% malaria, $5 \%$ measles, 3\% AIDS, $42 \%$ kondisi perinatal dan $9 \%$ penyebab lain. ${ }^{1}$ Selama ini upaya penurunan angka kematian balita merupakan salah satu prioritas dalam pembangunan kesehatan. Dalam dokumen Program Pembangunan Nasional (Propenas) 2000-2004 upaya-upaya ini tercabtum dalam tiga program yaitu lingkungan sehat, perilaku sehat, dan pemberdayaan masyarakat serta program upaya kesehatan dan program perbaikan gizi masyarakat. ${ }^{2}$

Pemberian ASI awal sangat dianjurkan karena ASI yang keluar pertama kali sangat bergizi dan mengandung antibodi yang dapat melindungi bayi baru lahir dari penyakit. Pengenalan makanan pendamping sebagai tambahan terhadap ASI mempunyai manfaat yang penting baik bagi kesehatan anak maupun ibu. Pengenalan dini makanan yang rendah energi dan gizi yang disiapkan dalam keadaan tidak higienis dapat mengakibatkan gizi kurang, infeksi organisme asing, dan kekebalan yang lebih rendah terhadap penyakit pada bayi. ${ }^{4}$

Menurut data SDKI tahun 2007, sebesar 32\% bayi di bawah umur 6 bulan mendapat ASI eksklusif dan hanya $44 \%$ bayi disusui dalam satu jam setelah kelahiran. Hasil ini berbeda jika dibandingkan tahun 2002-2003 yaitu 40\% bayi umur dibawah umur 6 bulan yang mendapatkan ASI eksklusif dan 39\% bayi yang disusui dalam satu jam setelah kelahiran. Keterlambatan mulainya pemberian ASI yang segera menunjukan bahwa adanya pemberian makanan dan minuman selain ASI yang diberikan pada usia dini dalam masa antara kelahiran dan pemberian ASI pertama kali. Berdasarkan data SDKI tahun 2007 sebesar $65 \%$ bayi yang dilahirkan mendapatkan makanan pralaktasi selain ASI pada tiga hari pertama kehidupan persentase ini meningkat dibandingkan dengan SDKI 2002-2003 yang hanya $45 \%{ }^{3}$ 
Tujuan penelitian secara umum untuk mengetahui hubungan pemberian makanan pralaktasi terhadap kelangsungan hidup bayi di Indonesia. Secara khusus untuk mengetahui : 1) Kelangsungan hidup bayi pada ibu yang memberikan makanan pralaktasi dan yang tidak memberikan makanan pralaktasi; 2) Faktor lain yang berpengaruh terhadap kelangsungan hidup bayi.

\section{METODE}

Jenis penelitian ini merupakan penelitian observasional dengan pendekatan cohort retrospective dimana data yang digunakan berupa data sekunder dan paparan telah terjadi sebelum penelitian dimulai. ${ }^{5,6}$ Penelitian ini dilakukan untuk mengetahui pengaruh pemberian makanan pralaktasi dengan kelangsungan hidup bayi diperoleh dari riwayat pemberian makanan pralaktasi setelah lahir pada periode 5 tahun sebelum survei dari studi analisis hasil Survei Demografi Kesehatan Indonesia (SDKI) 2007.

Variabel dalam penelitian ini terdiri dari variabel terikat yaitu kelangsungan hidup bayi, variabel bebas pemberian makanan pralaktasi dan variabel luar: umur ibu, pendidikan ibu, tempat tinggal, sosial ekonomi dan penolong persalinan. Penentuan subjek dalam penelitian ini dimulai dengan memilih sampel berdasarkan status paparan. Subjek yang sesuai dengan kriteria dalam penelitian ini adalah 2.886 responden.

\section{HASIL DAN PEMBAHASAN}

Subjek yang tercakup dalam penelitian adalah bayi berumur $0-12$ bulan dan menyusui setelah lahir dari ibu berumur 15-49 tahun. Analisis dilakukan terhadap variabel yang berhubungan dengan kelangsungan hidup bayi.

\section{Analisis Univariat}

Tabel 1. Distribusi frekuensi status kelangsungan hidup bayi menurut pemberian pralaktasi, umur, pendidikan, tempat tinggal, sosial ekonomi dan penolong persalinan

\begin{tabular}{lrc}
\hline \multicolumn{1}{c}{$\begin{array}{c}\text { Karakteristik } \\
\text { responden }\end{array}$} & Frekuensi & $\begin{array}{c}\text { Persen } \\
\text { (\%) }\end{array}$ \\
\hline Kelangsungan Hidup & & \\
Mati & 93 & 3,2 \\
Hidup & 2.793 & 96,8 \\
Pemberian & & \\
Pralaktasi & 1.904 & 66,0 \\
Ya & 982 & 34,0 \\
Tidak & & \\
Umur Ibu & & \\
<20 tahun & 172 & 6,0 \\
20-34 tahun & 2.214 & 76,7 \\
= 35 tahun & 500 & 17,3 \\
\hline Pendidikan & & \\
SD & 36 & 1,25 \\
SLTP & 713 & 24,7 \\
SLTA & 951 & 32,0 \\
Akademi & 166 & 5,8 \\
PT & 164 & 5,7 \\
Tempat Tinggal & & \\
Pedesaan & 1.544 & 53,5 \\
Perkotaan & 1.342 & 46,5 \\
Sosial Ekonomi & & \\
Rendah & 1.064 & 36,9 \\
Cukup & 614 & 21,3 \\
Mampu & 1.208 & 41,9 \\
Penolong Persalinan & & \\
Non Nakes & 1.021 & 35,4 \\
Nakes & 1.865 & 64,6 \\
\hline & &
\end{tabular}

Tabel 1 menunjukkan pada variabel pemberian makanan pralaktasi tersebut terdapat $66 \%$ bayi yang diberikan makanan pralaktasi setelah lahir. Jumlah ini menunjukkan bahwa masih banyak ibu-ibu yang tidak segera memberikan air susu ibu (ASI) pada satu jam pertama setelah kelahiran. Hal ini merupakan permasalahan yang perlu mendapatkan perhatian dalam pelayanan kesehatan, terutama untuk pencapaian penurunan angka kematian bayi. Jumlah kelangsungan hidup bayi pada penelitian ini adalah 
$93(3,2 \%)$ bayi yang mati dan sebesar $2793(96,8 \%)$ bayi yang hidup.

Jumlah responden umur $<20$ tahun adalah $6 \%$ dan $\geq 35$ tahun $17,3 \%$, hal ini menyatakan bahwa terdapat umur responden yang berada pada umur berisiko atau tidak berada pada umur reproduksi sehat. Analisis tingkat pendidikan responden, sebagian besar responden dengan pendidikan SLTA (32\%). Tingginya tingkat pendidikan responden seharusnya tidak menjadi masalah bagi pemberi pelayanan kesehatan dalam memberikan informasi atau pendidikan kesehatan. Perbedaan tempat tinggal responden antara perkotaan dan pedesaan tidak menunjukan perbedaan yang besar, 46,5\% responden tinggal di daerah perkotaan, responden lebih besar $(53,5 \%)$ berada di pedesaan. Responden dengan sosial ekonomi rendah sebesar $36,9 \%$. Pertolongan persalinan responden lebih banyak ditolong oleh tenaga kesehatan $(64,6 \%)$ dibanding dengan tenaga non kesehatan $(35,4 \%)$.

\section{Analisis Bivariat}

Analisis Log Rank dilakukan untuk melihat hubungan antara variabel bebas, pengganggu, dan variabel lainnya dari seluruh variabel yang diteliti dengan kelangsungan hidup bayi.

Tabel 2. Hasil analisis log rank kelangsungan hidup bayi berdasarkan pemberian pralaktasi, umur, pendidikan, tempat tinggal, sosial ekonomi, penolong persalinan dengan kelangsungan hidup bayi

\begin{tabular}{|c|c|c|c|c|c|}
\hline Variabel & $\begin{array}{c}\text { Events } \\
\text { Observed }\end{array}$ & $\begin{array}{c}\text { Events } \\
\text { expected }\end{array}$ & $\begin{array}{l}\text { Survivor } \\
\text { Function } \\
\text { (12 bulan) }\end{array}$ & $\begin{array}{l}\text { Log-rank } \\
\text { chi square }\end{array}$ & $p$ \\
\hline \multicolumn{6}{|c|}{ Pemberian pralaktasi } \\
\hline Ya & 52 & 31 & 92 & 4,97 & 0,026 \\
\hline Tidak & 41 & 62 & 89 & & \\
\hline \multicolumn{6}{|l|}{ Umur } \\
\hline$<20 \& \geq 35$ tahun & 37 & 22 & 86 & 14,63 & 0,000 \\
\hline 20-34 tahun & 56 & 71 & 92 & & \\
\hline \multicolumn{6}{|l|}{ Pendidikan } \\
\hline$\leq \mathrm{SD}$ & 39 & 30 & 87 & 5,73 & 0,057 \\
\hline SLTP & 24 & 22 & 91 & & \\
\hline SLTA keatas & 30 & 41 & 94 & & \\
\hline \multicolumn{6}{|l|}{ Tempat Tinggal } \\
\hline Pedesaan & 57 & 50 & 91 & 1,91 & 0,167 \\
\hline Perkotaan & 36 & 43 & 90 & & \\
\hline \multicolumn{6}{|l|}{ Sosial Ekonomi } \\
\hline Rendah & 56 & 34 & 83 & 22,63 & 0,000 \\
\hline Cukup & 11 & 19 & 98 & & \\
\hline Mampu & 26 & 40 & 94 & & \\
\hline \multicolumn{6}{|c|}{ Penolong Persalinan } \\
\hline Non Nakes & 42 & 32 & 88 & 4,69 & 0,030 \\
\hline Nakes & 51 & 61 & 92 & & \\
\hline
\end{tabular}

Keterangan: signifikansi $(p<0,05)$. 
Hasil analisis bivariat pada tabel 2, variabel pemberian makanan pralaktasi 3 hari sebelum ASI keluar menunjukkan hubungan bermakna dengan kelangsungan hidup bayi. Nilai Log Rank 4,97 dan $p<0,05$. Kelangsungan hidup bayi yang mendapatkan pralaktasi pada usia 1 bulan (99\%) tidak jauh berbeda dibandingkan dengan bayi yang tidak mendapatkan pralaktasi (98\%). Dampak pemberian pralaktasi terhadap kelangsungan hidup bayi semakin menurun dengan bertambahnya usia bayi, pada usia 12 bulan dampak pemberian makanan pralaktasi (92\%) dan tidak pralaktasi (89\%) tampak tidak berbeda (gambar 1). Bayi yang setelah lahir diberikan makanan pralaktasi selama tiga hari pertama sebelum ASI keluar dapat dikaitkan dengan budaya tradisional.

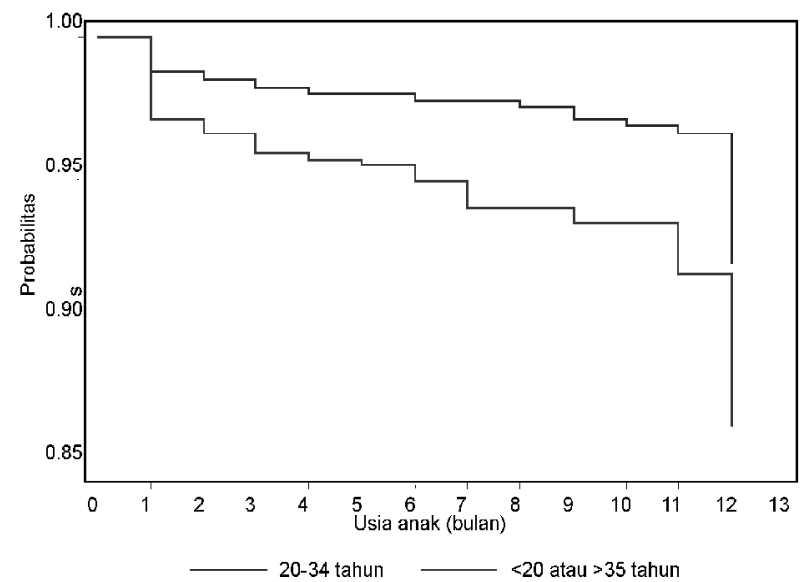

Gambar 1. Kurva Kaplan-Meier kelangsungan hidup bayi menurut pemberian makanan pralaktasi

Berdasarkan hasil analisis pada tabel 2 variabel yang signifikan yaitu umur ibu, nilai Log Rank 14,63 dan $p<0,05$. Kelangsungan hidup bayi pada usia 1 bulan lebih tinggi pada ibu yang berumur 20-34 tahun (98\%) dibandingkan dengan ibu berumur $<20$ dan $\geq$ 35 tahun (97\%). Kelangsungan hidup bayi menurun lebih nyata pada usia bayi 12 bulan dimana pada ibu yang berumur $<20$ tahun dan $\geq 35$ tahun $(86 \%)$ dan pada ibu yang berumur 20-34 tahun kelangsungan hidup bayi di usia 12 bulan turun menjadi $92 \%$ (Gambar 2).

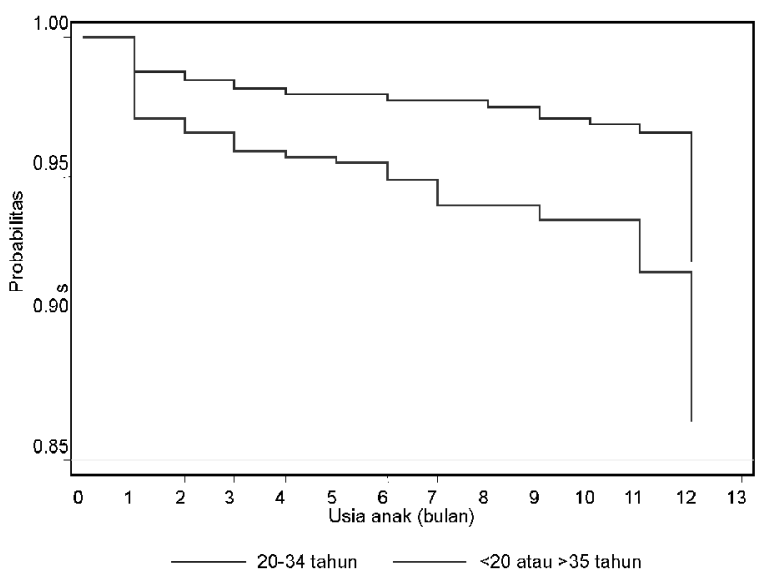

Gambar 2. Kurva Kaplan-Meier kelangsungan hidup bayi menurut umur

Tingkat pendidikan wanita menjadi indikator terhadap perilaku modernisasi yang diadopsi oleh keluarga. Wanita berpendidikan lebih tinggi cenderung memiliki probabilitas untuk meningkatkan kelangsungan hidup dengan tidak memberikan makanan pralaktasi pada bayi dibandingkan dengan wanita yang pendidikannya lebih rendah. Pada Gambar 3 diketahui pada wanita berpendidikan SLTP dan SLTA ke atas kelangsungan hidup bayi pada usia 1 bulan lebih tinggi (99\%) dibandingkan dengan wanita berpendidikan SD (98\%). Pada usia anak 12 bulan kelangsungan hidup bayi turun menjadi $87 \%$ pada ibu pendidikan SD, 91\% pada ibu pendidikan SLTP dan 94\% pada ibu pendidikan SLTA keatas (nilai Log Rank 5,73 dan $p>0,05$ ). Secara logika, wanita yang berpendidikan lebih tinggi lebih memahami arti pentingnya ASI bagi kesehatan anak.

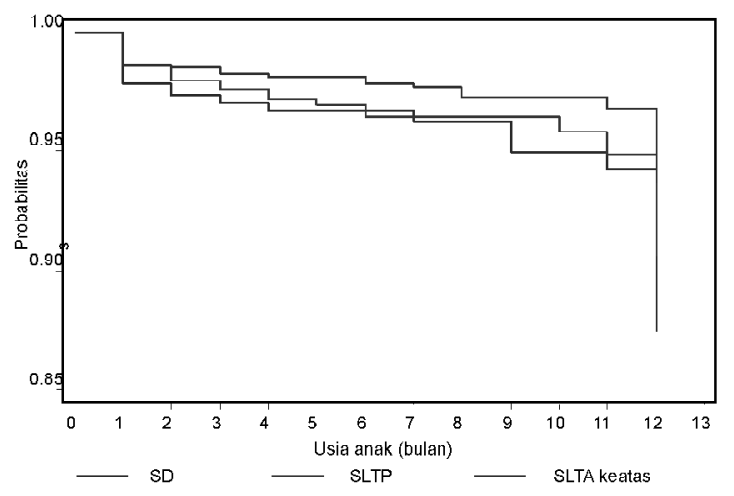

Gambar 3. Kurva Kaplan-Meier kelangsungan hidup bayi menurut pendidikan ibu 
Pada Gambar 4 tampak bahwa probabilitas kelangsungan hidup bayi pada wanita yang bertempat tinggal di pedesaan dan perkotaan tidak mengalami perbedaan yang besar. Kelangsungan hidup bayi pada usia 1 bulan di perkotaan (99\%) dan pedesaan (98\%). Perbedaan yang nyata terjadi pada usia anak 12 bulan dimana bayi yang tinggal di perkotaan kelangsungan hidup nya menjadi (90\%) lebih rendah dibandingkan dengan bayi dipedesaan (91\%) (nilai Log Rank 1,91 dan $p>0,05$ ). Hal ini membuktikan bahwa modernisasi tidak secara langsung dapat meningkatkan kelangsungan hidup bayi.

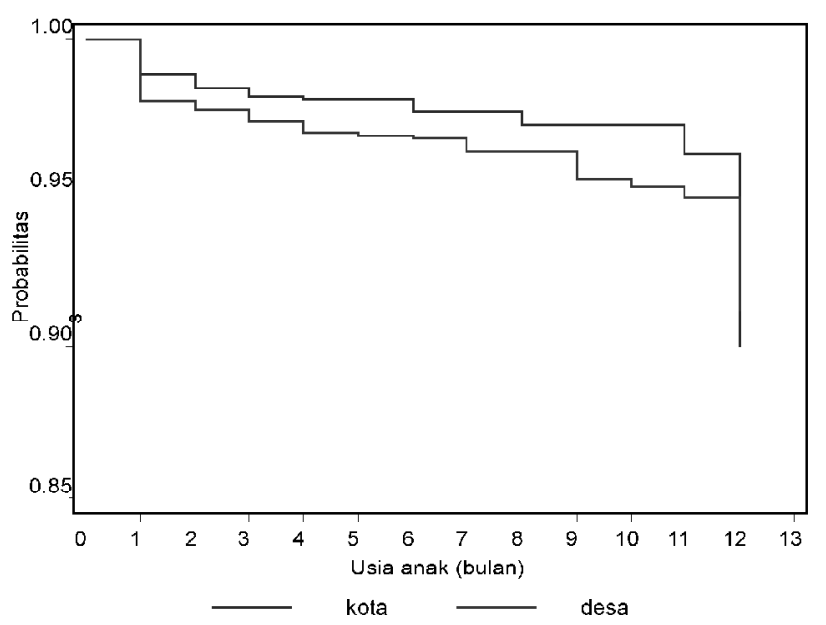

Gambar 4. Kurva Kaplan-Meier kelangsungan hidup bayi menurut tempat tinggal

Kemiskinan dalam penelitian ini diukur dari indeks kekayaan (5 kategori), kemudian disederhanakan menjadi 3 kategori, yaitu: rendah, cukup dan mampu. Kemiskinan merupakan salah satu akibat dari tertinggalnya keluarga dalam proses modernisasi pembangunan. Pada Gambar 5 tampak bahwa makin rendah sosial ekonomi suatu keluarga, makin singkat probabilitas kelangsungan hidup bayi. Kelangsungan hidup bayi usia 1 bulan pada sosial ekonomi mampu (99\%), cukup (98\%) dan rendah (98\%). Kelangsungan hidup bayi terdapat penurunan pada umur 12 bulan dimana sosial ekonomi mampu (94\%), cukup (98\%) dan rendah (83\%). Ada hubungan yang bermakna antara sosial ekonomi dengan kelangsungan hidup bayi (nilai Log Rank 22,63 dan $p<0,05$ ).

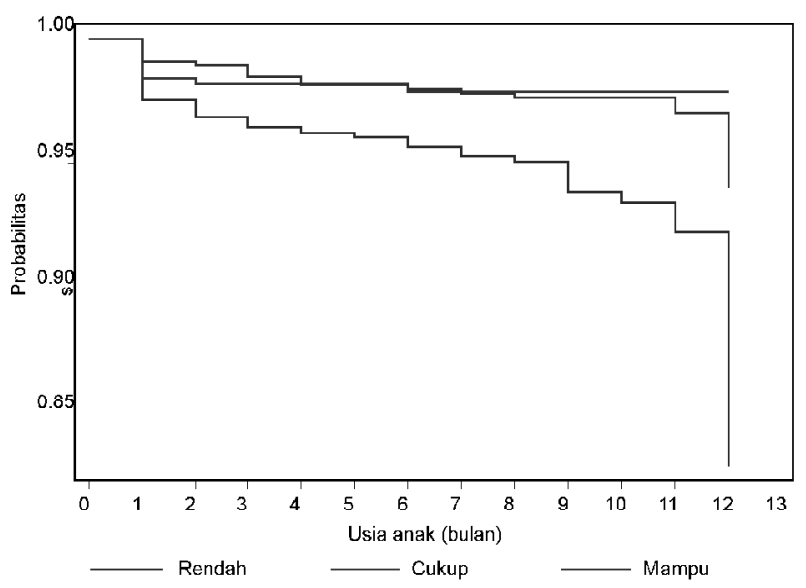

Gambar 5. Kurva Kaplan-Meier kelangsungan hidup bayi menurut sosial ekonomi

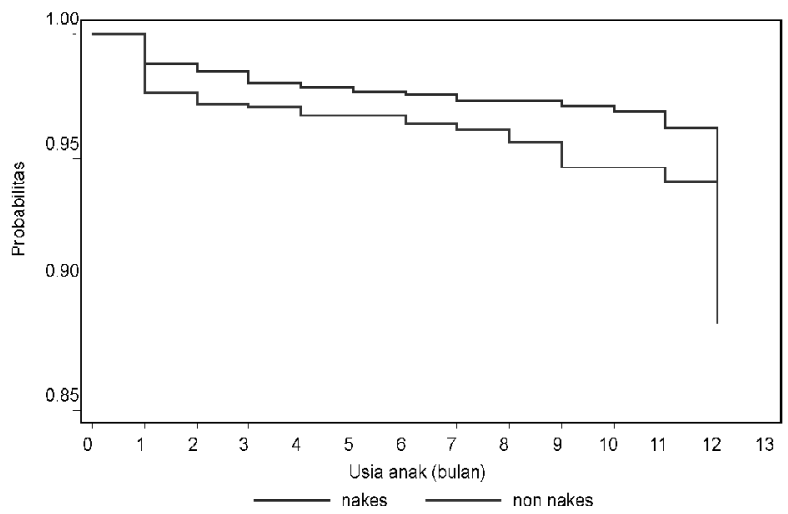

Gambar 6. Kurva Kaplan-Meier kelangsungan hidup bayi menurut penolong persalinan

Pada Gambar 6 diketahui wanita yang mendapatkan pertolongan persalinan oleh tenaga non kesehatan memiliki probabilitas kelangsungan hidup bayi pada usia 1 bulan lebih rendah (98\%) dibanding wanita yang mendapatkan pertolongan persalinan oleh tenaga kesehatan (99\%). Pada usia anak 12 bulan kelangsungan hidup bayi pada ibu yang mendapatkan pertolongan persalinan oleh tenaga non kesehatan semakin menurun menjadi (88\%) dan oleh tenaga kesehatan (92\%). Ada hubungan yang bermakna antara penolong persalinan dengan kelangsungan hidup bayi, nilai Log Rank 4,69 dan p<0,05. Perawatan oleh tenaga kesehatan digunakan sebagai indikator terhadap perilaku wanita yang telah 
mengadopsi teknologi kedokteran modern. Hal ini menunjukkan bahwa perawatan setelah melahirkan oleh tenaga kesehatan berpengaruh positif terhadap perilaku ibu untuk tidak melakukan pemberian makanan pralaktasi pada bayi dalam tiga hari pertama setelah kelahiran.

Tabel 3. Hubungan antara umur, pendidikan, tempat tinggal, sosial ekonomi dan penolong persalinan dengan pemberian makanan pralaktasi

\begin{tabular}{|c|c|c|c|c|c|c|}
\hline \multirow{3}{*}{ Variabel } & \multicolumn{4}{|c|}{ Pemberian Makanan Pralaktasi } & \multirow[b]{3}{*}{$\mathbf{p}$} & \multirow[b]{3}{*}{$\chi^{2}$} \\
\hline & \multicolumn{2}{|c|}{$\mathrm{Ya}$} & \multicolumn{2}{|c|}{ Tidak } & & \\
\hline & $\mathbf{n}$ & $\%$ & $\mathbf{n}$ & $\%$ & & \\
\hline \multicolumn{7}{|l|}{ Umur } \\
\hline$<20 \& \geq 35$ tahun & 453 & 67,4 & 219 & 32,6 & 0,369 & 0,80 \\
\hline 20-34 tahun & 1.451 & 65,5 & 763 & 34,5 & & \\
\hline \multicolumn{7}{|l|}{ Pendidikan } \\
\hline SD & 545 & 61 & 347 & 39 & 0,000 & 16,46 \\
\hline SLTP & 469 & 65,8 & 244 & 34,2 & & \\
\hline SLTA keatas & 890 & 69,5 & 391 & 30,5 & & \\
\hline \multicolumn{7}{|l|}{ Tempat Tinggal } \\
\hline Pedesaan & 954 & 61,8 & 590 & 38,2 & 0,000 & 25,92 \\
\hline Perkotaan & 950 & 70,8 & 392 & 29,2 & & \\
\hline \multicolumn{7}{|l|}{ Sosial Ekonomi } \\
\hline Rendah & 634 & 59,6 & 430 & 40,4 & 0,000 & 30,67 \\
\hline Cukup & 430 & 70 & 184 & 30 & & \\
\hline Mampu & 840 & 69,5 & 368 & 30,5 & & \\
\hline \multicolumn{7}{|c|}{ Penolong Persalinan } \\
\hline Non Nakes & 660 & 64,6 & 361 & 35,4 & 0,264 & 1,25 \\
\hline Nakes & 1.244 & 66,7 & 621 & 33,3 & & \\
\hline
\end{tabular}

Berdasarkan hasil analisis tersebut, variabel luar memiliki hubungan yang bermakna secara statistik dan biologik dengan kelangsungan hidup bayi maupun pemberian makanan pralaktasi. Variabel tersebut akan diikutkan dalam analisis multivariat untuk melihat hubungan pemberian makanan pralaktasi dan kelangsungan hidup bayi dengan menyertakan variabel luar serta untuk memastikan adanya confounding.

\section{Analisis Stratifikasi}

Analisis Stratifikasi adalah cara untuk mengontrol faktor pengganggu dengan mengevaluasi pengaruh paparan terhadap penyakit secara terpisah pada masing-masing tingkat faktor pengganggu. Untuk membuktikan seberapa besar pengaruh tersebut maka dilakukan analisis stratifikasi. Hasil analisis dapat dilihat pada Tabel 4 
Tabel 4. Stratifikasi pemberian makanan pralaktasi dengan kelangsungan hidup bayi berdasarkan umur, pendidikan, tempat tinggal, sosial ekonomi, penolong persalinan dan wilayah

\begin{tabular}{|c|c|c|c|c|}
\hline \multirow[b]{2}{*}{ Variabel } & \multirow{2}{*}{$\begin{array}{c}\text { Pemberian } \\
\text { Makanan } \\
\text { Pralaktasi }\end{array}$} & \multicolumn{2}{|c|}{ Kelangsungan Hidup } & \multirow{2}{*}{$\begin{array}{c}\text { HR } \\
(95 \% \mathrm{Cl})\end{array}$} \\
\hline & & $\begin{array}{c}\text { Event } \\
\mathrm{n}(\%)\end{array}$ & $\begin{array}{c}\text { Sensor } \\
\mathbf{N}(\%)\end{array}$ & \\
\hline \multicolumn{5}{|l|}{ Umur } \\
\hline \multirow[t]{2}{*}{$\leq 20 \& \geq 35$ tahun } & $\mathrm{Ya}$ & $25(5,5)$ & $428(94,5)$ & 1,07 \\
\hline & Tidak & $12(5,5)$ & $207(94,5)$ & $(0,53-2,13)$ \\
\hline \multirow[t]{2}{*}{ 20-34 tahun } & $\mathrm{Ya}$ & $27(1,9)$ & $1.424(98,1)$ & 0,45 \\
\hline & Tidak & $29(3,8)$ & $734(96,2)$ & $(0,27-0,77)$ \\
\hline \multicolumn{5}{|l|}{ Pendidikan } \\
\hline \multirow[t]{2}{*}{ SD } & $\mathrm{Ya}$ & $19(3,5)$ & $526(96,5)$ & 0,58 \\
\hline & Tidak & $20(5,8)$ & $327(94,2)$ & $(0,31-1,10)$ \\
\hline \multirow[t]{2}{*}{ SLTP } & $\mathrm{Ya}$ & $10(2,1)$ & $459(97,9)$ & 0,33 \\
\hline & Tidak & $14(5,7)$ & $230(94.3)$ & $(0,14-0,75)$ \\
\hline \multirow[t]{2}{*}{ SLTA Keatas } & Ya & $23(2,6)$ & $867(97,4)$ & 1,41 \\
\hline & Tidak & $7(1,8)$ & $384(98,2)$ & $(0,60-3,30)$ \\
\hline \multicolumn{5}{|l|}{ Tempat Tinggal } \\
\hline \multirow[t]{2}{*}{ Pedesaan } & $\mathrm{Ya}$ & $28(2,9)$ & $926(97,1)$ & 0,56 \\
\hline & Tidak & $29(4,9)$ & $561(95,1)$ & $(0,33-0,94)$ \\
\hline \multirow[t]{2}{*}{ Perkotaan } & Ya & $24(2,5)$ & $926(97,5)$ & 0,83 \\
\hline & Tidak & $12(3,1)$ & $380(96,9)$ & $(0,41-1,66)$ \\
\hline \multicolumn{5}{|l|}{ Sosial Ekonomi } \\
\hline \multirow[t]{2}{*}{ Rendah } & Ya & $29(4,6)$ & $605(95,4)$ & 0,67 \\
\hline & Tidak & $27(6,3)$ & $403(93,7)$ & $(0,39-1,14)$ \\
\hline \multirow[t]{2}{*}{ Cukup } & $\mathrm{Ya}$ & $4(0,9)$ & $426(99,1)$ & 0,24 \\
\hline & Tidak & $7(3,8)$ & $177(96,2)$ & $(0,07-0,84)$ \\
\hline \multirow[t]{2}{*}{ Mampu } & $\mathrm{Ya}$ & $19(2,3)$ & $821(97,7)$ & 1,17 \\
\hline & Tidak & $7(1,9)$ & $361(98,1)$ & $(0,49-2,78)$ \\
\hline \multicolumn{5}{|l|}{ Penolong Persalinan } \\
\hline \multicolumn{5}{|l|}{ Non Nakes } \\
\hline & $\mathrm{Ya}$ & $27(4,1)$ & $633(95,9)$ & 0,93 \\
\hline \multirow[t]{3}{*}{ Nakes } & Tidak & $15(4,2)$ & $346(95,8)$ & $(0,49-1,76)$ \\
\hline & $\mathrm{Ya}$ & $25(2,0)$ & $1.219(98,0)$ & 0,46 \\
\hline & Tidak & $26(4,2)$ & $595(95,8)$ & $(0,26-0,80)$ \\
\hline
\end{tabular}

\section{Analisis Multivariat}

Analisis multivariat dilakukan untuk menindaklanjuti analisis bivariat yang dilakukan sebelumnya. Analisis multivariabel untuk kelangsungan hidup bayi menggunakan Cox's Regression. Analisis tersebut dilakukan untuk mengetahui pengaruh pemberian makanan pralaktasi, umur ibu, pendidikan ibu, sosial ekonomi dan penolong persalinan dengan kelangsungan hidup bayi. Uji statistik yang digunakan pada analisis multivariat adalah analisis Cox Regression dengan tingkat kemaknaan $p<0,05(\mathrm{Cl}: 95 \%)$. 


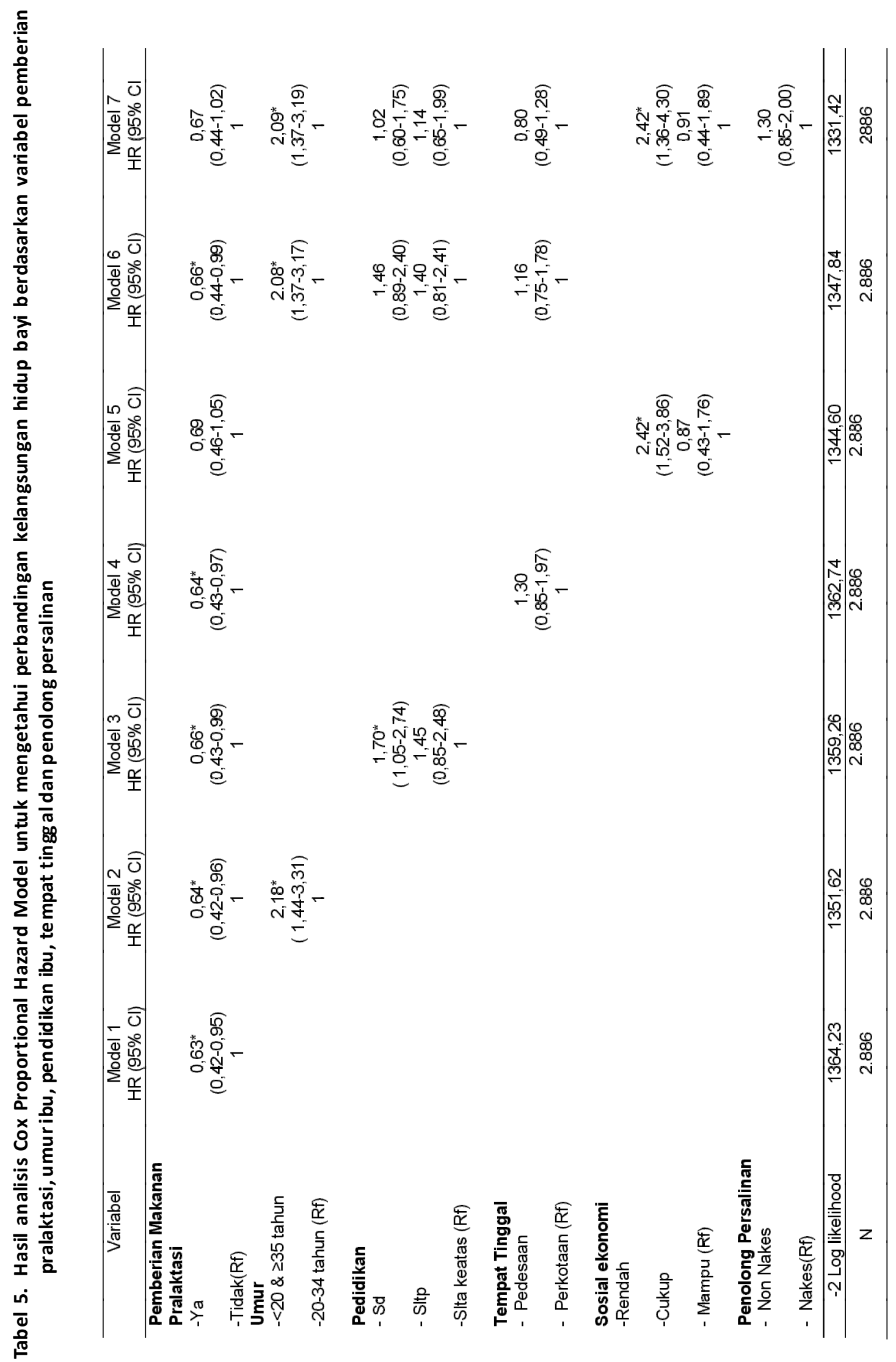


Model 1 menjelaskan hubungan variabel utama terhadap kelangsungan hidup bayi tanpa dilakukan adjusted dengan variabel lain. Kelangsungan hidup bayi yang mendapatkan pralaktasi adalah 0,63 kali dibandingkan dengan kelangsungan hidup bayi yang tidak mendapatkan pralaktasi. Hasil analisis menunjukkan hubungan yang bermakna antara pemberian makanan pralaktasi dengan kelangsungan hidup bayi. Model selanjutnya dilakukan analisis dengan menyertakan variabel lain. Dari hasil analisis tersebut, model 2 sebagai model yang lebih efektif dalam melihat variabel yang sangat berpengaruh terhadap kelangsungan hidup bayi. Variabel umur yang diikutsertakan keadekuatan-nya dicerminkan dari nilai HR sebesar 0,64 (95\%Cl:0,42-0,96).

\section{Hubungan Pemberian Makanan Pralaktasi dan Kelangsungan Hidup Bayi}

Bayi baru lahir mengalami perubahan saat memasuki dunia di luar kandungan. Tindakan yang relatif murah dan mudah untuk meningkatkan kesehatan dan kelangsungan hidup bayi adalah pemberian ASI segera setelah lahir. Menyusui setelah melahirkan bermanfaat untuk ibu dan bayi. Bayi mendapatkan kolostrum yang mengandung anti bodi untuk mencegah infeksi. Fenomena praktik menyusui setelah lahir merupakan hal yang menarik untuk dikaji, karena biasanya setelah melahirkan ibu mengalami kelelahan yang amat sangat, disamping air susu belum keluar dengan lancar, sehingga seringkali tidak disusui. Keterlambatan memulai menyusui menunjukkan adanya semacam pemberian makanan atau minuman pralaktasi antara jarak kelahiran dengan pemberian ASI pertama kali. ${ }^{8}$

Berdasarkan hasil analisis data bivariabel maupun multivariabel, pemberian makanan pralaktasi dengan kelangsungan hidup bayi menunjukkan hubungan yang bermakna. Penelitian yang sama dilakukan di Ghana bahwa pemberian makanan pralaktasi tiga kali lipat meningkatkan risiko kematian pada bayi usia 2 sampai 28 hari OR: 3,12 (Cl: 1,19$8,22)$, tetapi tidak ada peningkatan yang bermakna secara statistik terhadap pemberian ASI predominan. ${ }^{9}$

Kelangsungan hidup bayi lebih tinggi pada bayi yang mendapatkan makanan pralaktasi dibandingkan dengan bayi yang tidak mendapatkan pralaktasi. Namun pada stratifikasi dengan variabel umur, pendidikan, tempat tinggal, sosial ekonomi dan penolong persalinan kelangsungan hidup bayi lebih tinggi pada yang tidak mendapatkan pralaktasi dibandingkan dengan bayi yang mendapatkan pralaktasi. Pada stratifikasi wilayah kelangsungan hidup bayi lebih tinggi pada bayi yang mendapatkan pralaktasi dibandingkan dengan yang tidak mendapatkan pralaktasi.

Pemberian pralaktasi lebih tinggi kelangsungan hidupnya dikarenakan bayi yang mendapatkan pralaktasi tetap mendapatkan pemberian ASI meskipun juga diberikan sedikit air minum atau minuman cairan lain yang disebut dengan ASI predominan dan dari lamanya bayi menyusui. Lama menyusui bayi sangat mempengaruhi keadaan gizi bayi dan ini sangat dipengaruhi oleh modernisasi yang terjadi dimasyarakat. Pada masyarakat tradisional persentase menyusui tinggi dan mempunyai rata-rata lama menyusui yang panjang, tetapi pada masyarakat modern biasanya keduanya rendah atau persentase menyusui tinggi dan lama menyusui yang rendah. Masyarakat desa cenderung mempertahankan aturan-aturan tradisional, sedangkan modernisasi dan westernisasi mempunyai kecenderungan untuk meninggalkan menyusui. Lama menyusui dapat dilakukan dengan cara memberikan ASI saja atau dengan memberikan campuran menggunakan susu botol. ${ }^{10}$

Penelitian yang dilakukan di Malaysia bahwa pertambahan lama menyusui selama 1 minggu ditemukan pada bulan pertama kehidupan bayi terjadi penurunan risiko kematian sebesar 16 kematian per 1000 sedangkan pada umur 6-12 bulan terjadi penurunan 1,8 kematian per $1000 .{ }^{11}$ Penelitian yang sama juga dilakukan di Indonesia bahwa bayi yang 
disusui dengan durasi 6 bulan atau lebih memiliki kelangsungan hidup 33,3 kali lebih baik daripada bayi yang disusui kurang dari 4 bulan dan bayi yang disusui dengan durasi 4-5 bulan memiliki kelangsungan hidup 2,6 kali lebih baik daripada bayi yang disusui kurang dari 4 bulan. ${ }^{12}$

Kelangsungan hidup bayi juga dapat ditingkatkan dengan imunisasi karena banyak penyakit yang dapat dicegah dengan pemberian imunisasi. Kelangsungan hidup anak yang diberikan pralaktasi dapat dipengaruhi oleh imunisasi yang tidak dilihat pada penelitian ini. Penelitian yang dilakukan di India bahwa bayi yang mendapatkan vaksin BCG dan DPT dapat menurunkan 1,5 sampai dua pertiga risiko kematian pada bayi. ${ }^{13}$

Menyusui juga merupakan tradisi atau praktik turun temurun yang saat ini mulai terancam akibat modernisasi. Banyak penelitian menunjukan bahwa melemahnya tradisi dalam pemberian ASI merupakan akibat terjadinya proses medernisasi. Salah satu bentuk pemahaman gizi dan kesehatan modern yang salah yaitu pemberian makanan dan minuman dalam bentuk formula, hal ini dilakukan seiring dengan ditinggalkannya praktik perawatan tradisional secara perlahan-lahan. Pemberian pralaktasi terbanyak pada penelitian ini adalah dengan pemberian susu formula, hal ini menunjukkan bahwa adanya pemahaman bahwa memberikan susu formula merupakan budaya modern. ${ }^{14}$

Sesuai dengan penelitian yang dilakukan di India dan Nepal sekitar $30 \%$ bayi mendapatkan makanan pralaktasi diantaranya $56,6 \%$ mendapatkan susu formula. Sekitar $76,6 \%$ bayi mendapatkan makanan pralaktasi pada 1- 6 jam pertama kehidupan dan hanya $16,7 \%$ mendapatkan makanan pralaktasi antara 1 jam pertama kehidupan. ${ }^{15}$ Penelitian lain di Tanzania ditemukan bahwa $25 \%$ bayi diberikan makanan pralaktasi, jenis makanan pralaktasi yang diberikan adalah air gula untuk persalinan di rumah sakit dan air biasa untuk persalinan di rumah. ${ }^{16}$

Alasan pemberian minuman atau makanan selain ASI adalah khawatir bila anak tidak cukup makan, faktor budaya dan tradisi seperti pemberian madu, air gula dan buah yang dihaluskan, sehingga bayi tidak segera disusui dan adanya kepercayaan masyarakat bahwa colostrum beracun, sehingga orang tua takut akan terjadi diare pada anaknya. ${ }^{17}$ Pada suku Banjar di Kalimantan Selatan ibu yang tinggal di pedesaan memberikan madu dan air gula sebagai makanan pralaktasi, dengan alasan yang berkaitan dengan kepercayaan yang ada pada Suku Banjar bahwa makanan tersebut berkhasiat untuk mem-bersihkan alat pencernaan bayi. Jika bayi dari kecil sudah mendapatkan makanan yang manis maka pada saat dewasa akan mempunyai tutur kata yang manis, ramah dan disenangi oleh orang. ${ }^{18}$

Pemberian makanan pralaktasi juga dipengaruhi oleh kepercayaan, ada kepercayaan yg berbeda antara keluarga muslim dan hindu. Manfaat pralaktasi dari keluarga muslim adalah pemberian gula dan garam dapat membantu bayi buang air kecil, membersihkan perut, menjaga tubuh tetap hangat sedangkan pada keluarga Hindu pralaktasi dengan memberikan madu bermanfaat untuk mengeluarkan mekonium, mengurangi sakit perut dan sebagai pencahar namun masih banyak keluarga muslim dan hindu yang masih meyakini pentingnya kolostrum. ${ }^{19}$

\section{Hubungan Umur, Pendidikan, Tempat Tinggal, Sosial Ekonomi dan Penolong Persalinan dengan Kelangsungan Hidup Bayi}

Pada analisis univariat terdapat $6 \%$ umur ibu $<$ 20 tahun dan $17,3 \% \geq 35$ tahun, hal ini menunjukan bahwa terdapat ibu pada umur berisiko atau tidak dalam masa reproduksi sehat. Pada penelitian ini jumlah bayi yang mati lebih besar pada ibu umur $<20$ tahun dan $\geq 35$ tahun. Analisis bivariatl umur dan kelangsungan hidup bayi menunjukan hubungan yang bermakna. Analisis bivariat umur dan pemberian makanan pralaktasi, bayi yang diberikan pralaktasi lebih besar pada ibu umur $\geq 35$ tahun.

Peneliti menyimpulkan bahwa risiko kematian dan pemberian makanan pralaktasi lebih besar terjadi pada ibu umur $<20$ dan $\geq 35$ tahun, namun umur ibu 
tidak bermakna secara statistik terhadap pemberian pralaktasi. Persalinan pada usia $<20$ tahun lebih berisiko untuk terjadinya kematian pada bayi karena mekanisme biologis belum sempurna. Ibu masih mengalami perkembangan pada tubuhnya dan fungsi organ reproduksi belum sempurna. Pada usia tersebut akan terjadi kompetisi nutrisi antara ibu dan bayi, serta dari faktor psikologis belum siap menjadi seorang ibu. Sedangkan umur $\geq 35$ tahun merupakan fase premenopause dimana alat reproduksi sudah tidak berfungsi secara optimal sehingga akan mengganggu asupan nutrisi ke janin.

Penelitijuga berpendapat bahwa kehamilan pada umur tersebut secara sosial merupakan indikator dari suatu kehamilan yang tidak direncanakan, sehingga ibu cenderung mengabaikan pemeriksaan kehamilannya. Pada umur tersebut ibu sering tidak membekali diri untuk segala sesuatu yang seharusnya dipersiapkan selama kehamilan, seperti pengetahuan tentang pemeriksaan kehamilan, kebutuhan gizi selama kehamilan serta perilaku yang mendukung untuk kesehatan selama kehamilan. Kehamilan pada kondisi tersebut mengakibatkan adanya perilaku yang tidak mendukung kesehatan bagi ibu dan janin. Dengan demikian untuk mengurangi risiko outcome kelahiran yang kurang baik, perlu memperhatikan faktor umur. Umur reproduktif sehat yaitu 20-34 tahun merupakan saat yang lebih baik untuk menghindari risiko terjadinya kematian bayi.

Penelitian yang sama dilakukan di Pakistan bahwa ibu yang bersalin pada usia kurang dari 13 tahun sebesar 20\%, pada usia $14-18$ tahun $15,2 \%$ dan pada usia lebih dari 18 tahun sebesar 9,3\% kehilangan anak pertama mereka pada usia 48 bulan. Kelangsungan hidup anak kedua dengan usia ibu saat persalinan kurang dari 13 tahun sebesar 5,8\% dari persalinan dan 19,1\% untuk ibu usia $14-18,6,6 \%$ untuk ibu yang usianya lebih dari 18 tahun kehilangan anak mereka pada usia 48 bulan. ${ }^{19}$

Pendidikan ibu menunjukan hubungan yang tidak bermakna dengan kelangsungan hidup bayi (tabel 2). Semakin tinggi tingkat pendidikan ibu, kelangsungan hidup bayi akan semakin tinggi. Hal ini sesuai dengan penelitian di Ghana bahwa ada hubungan yang positif antara pendidikan ibu dengan kematian bayi. Anak-anak dari ibu yang berpendidikan tinggi menunjukan angka kematian bayi yang rendah. Ada hubungan yang bermakna antara pendidikan ibu dengan diare, infeksi saluran pernapasan akut (ISPA) dan malnutrisi. Ibu dengan pendidikan rendah menunjukan tingginya angka kesakitan disebabkan oleh diare, ISPA dan malnutrisi. ${ }^{20}$ Dan penelitian Bangladesh juga menjelaskan bahwa risiko kematian anak usia 6-35 bulan lebih tinggi pada ibu yang berpendidikan rendah yaitu 1,5 kali dibandingkan dengan ibu yang berpendidikan tinggi. ${ }^{21 .}$

Faktor pendidikan ibu merupakan faktor pengaruh yang kuat terhadap kematian balita. Pendidikan pada hakekatnya merupakan usaha sadar untuk mengembangkan kepribadian dan kemampuan di dalam dan luar sekolah seumur hidup sehingga makin matang dalam menghadapi dan memecahkan berbagai masalah termasuk masalah kesehatan dalam rangka menekan risiko kematian.

Pendidikan ibu sangat erat kaitannya dengan reaksi serta pembuatan keputusan rumah tangga terhadap penyakit. Ini terlihat bahwa kematian balita yang rendah dijumpai pada golongan wanita yang mempunyai pendidikan yang tinggi. Pendidikan wanita telah terbukti berkaitan erat dengan penerimaan budaya modern dalam keluarga, bahkan terbukti keputusan bersama terjadi dalam penggunaan teknologi kesehatan modern untuk ibu dan anak. Pendidikan juga lebih berpengaruh sebagai perilaku modernisasi dan pemberian pralaktasi masih dianggap bagian dari perilaku budaya tradisional. ${ }^{14}$

Analisis berdasarkan tempat tinggal 53,5\% responden tinggal di daerah pedesaan. Kelangsungan hidup bayi lebih tinggi pada ibu yang tinggal di daerah pedesaan dibandingkan dengan yang tinggal di perkotaan. Hasil analisis bivariat tempat tinggal dan kelangsungan hidup bayi tidak menunjukan hubungan bermakna. Hal ini berbeda dengan penelitian Indonesia yang menggunakan data SDKI tahun 2002- 
2003 terhadap 11.588 bayi yang lahir hidup, ditemukan angka kematian bayi adalah 2,03\% yaitu $1,41 \%$ di perkotaan dan 2,46\% dipedesaan. Proporsi kematian bayi di daerah pedesaan ditemukan 1,74 kali lebih besar daripada di daerah perkotaan. ${ }^{22 .}$

Perbedaan probabilitas kelangsungan hidup bayi di perkotaan dan di pedesaan dapat terjadi karena pebedaan ketersediaan fasilitas pelayanan kesehatan, tenaga penolong persalinan dan perbedaan akses menuju fasilitas kesehatan. Selain itu, umumnya masyarakat desa masih memegang teguh adat kebiasaan setempat yang berdampak buruk pada kesehatan bayi. Bila terdapat kebiasaan yang tidak mendukung perilaku kesehatan maka risiko kematian bayi yang terjadi akan lebih tinggi. Misalnya kebiasaan pemberian pralaktasi, walaupun ibu-ibu yang tinggal didaerah pedesaan lebih banyak yang pernah menyusui anaknya, dibanding ibu yang tinggal di perkotaan akan tetapi ibu-ibu di daerah perkotaan hanya sedikit yang memberikan makanan padat pada bayi usia kurang 1 bulan dibandingkan ibu-ibu di daerah pedesaan. ${ }^{14,22}$

Masyarakat kota pada umumnya berada pada tingkat sosial ekonomi, pendidikan, pendapatan serta penyediaan air dan sanitasi yang lebih baik. Selain itu, pelayanan kesehatan modern dan tenaga kesehatan lebih terkonsentrasi dikota. Sehubungan dengan hal tersebut, wanita dari pedesaan dapat dianggap lebih tertinggal dalam modernisasi dibandingkan dengan wanita dari daerah perkotaan. ${ }^{14}$

Pada penelitian ini pengukuran tingkat sosial ekonomi berdasarkan kondisi rumah sampai dengan kepemilikan barang bergerak. Pendekatan aset kepemilikan barang rumah tangga merupakan salah satu cara untuk mengidentifikasi perspektif ekonomi, informasi kesehatan, nutrisi dan keadaan populasi. ${ }^{23}$ Pada analisis univariabel terdapat $36,9 \%$ responden dengan sosial ekonomi rendah. Hasil analisis bivariabel menunjukkan hubungan yang bermakna antara status ekonomi dengan kelangsungan hidup bayi. Probabilitas kelangsungan hidup bayi meningkat dengan makin meningkatnya status ekonomi.
Hal ini sesuai dengan penelitian di Purworejo didapatkan hasil anak dengan status ekonomi rendah memiliki risiko mati 3,75 kali dibandingkan dengan anak dari keluarga ekonomi tinggi. ${ }^{24}$. Hal ini dikarenakan pengetahuan, kesadaran akan masalah kesehatan serta pencegahan penyakit yang rendah, lebih banyak didapat pada masyarakat ekonomi lemah, pendidikan yang rendah dikaitkan dengan kemiskinan dan kurang gizi yang dapat menyebabkan rendahnya kemungkinan anak untuk hidup. ${ }^{25}$.

Hubungan status ekonomi dengan masalah kesehatan bukan penyebab langsung, namun lebih berkaitan dengan kemampuan keluarga dalam penyediaan makanan bergizi, tempat tinggal yang memenuhi syarat kesehatan dan biaya untuk pemeliharaan kesehatan. Hal ini tidak terlepas dari mahalnya biaya yang harus dikeluarkan untuk mendapatkan fasilitas pelayanan kesehatan beserta obat-obatan. ${ }^{26}$ Persiapan pemberian makanan dan jenis fasilitas toilet yang digunakan dalam rumah tangga berpengaruh terhadap status kesehatan dan kematian anak. Anak yang menggunakan semaksemak untuk pembuangan tinja mempunyai risiko lebih tinggi kematian dibanding mereka yang menggunakan kamar kecil lubang atau toilet. ${ }^{27}$

Pada analisis univariat terdapat $35,4 \%$ responden persalinan ditolong oleh tenaga non kesehatan. Hasil analisis bivariat menunjukkan hubungan yang bermakna antara penolong persalinan dengan kelangsungan hidup bayi. Probabilitas kelangsungan hidup bayi lebih tinggi pada ibu yang bersalin dengan tenaga kesehatan dibandingkan dengan ibu yang bersalin dengan tenaga non kesehatan. Penolong persalinan merupakan faktor penentu keberhasilan menyusui dini dan mengurangi pemberian pralaktasi.

Penelitian yang dilakukan di Bangladesh penolong persalinan oleh tenaga kesehatan meningkatkan 1,5 kali kelangsungan hidup bayi dibanding dengan persalinan yang bukan ditolong oleh tenaga kesehatan professional. ${ }^{27}$ Pertolongan 
persalinan yang dilakukan dukun sering dalam keadaan kurang steril, sehingga kematian postneonatal lebih tinggi pada ibu yang melahirkan di rumah dan ditolong oleh tenaga non kesehatan. Walaupun dukun telah mendapat pelatihan, namun keterampilannya belum memadai, terutama persalinan dengan penyulit. ${ }^{28}$

Pemilihan penolong persalinan belum didasarkan pada pemikiran preventif. Ibu yang merasa kehamilannya tidak sehat $93,9 \%$ memilih bidan sebagai penolong persalinan. Ibu yang merasa membutuhkan tenaga kesehatan dalam menolong persalinan $78,3 \%$ memilih bidan sebagai penolong persalinan dan $21,7 \%$ memilih dukun bayi sebagai penolong persalinan. Walaupun fasilitas kesehatan telah tersedia sampai ke pelosok pedesaan, namun pemilihan penolong persalinan juga ditentukan oleh kebutuhan ibu, pendidikan dan status ekonomi. ${ }^{29}$

Berdasarkan uraian tersebut di atas, terbukti bahwa kelangsungan hidup anak tidak ditentukan oleh satu faktor penyebab saja, melainkan ditentukan oleh banyak faktor yang saling berkaitan antara satu dengan lainnya. Usaha menurunkan kematian hanya bisa dilakukan multidisipliner dan lintas sektoral. Walaupun demikian pemberian prioritas, intervensi yang mudah dan murah seperti pemberian ASI terutama ASI segera lahir perlu ditingkatkan. Pada hakikatnya kehidupan janin dan bayi merupakan proses kelanjutan. Pertumbuhan dan perkembangan manusia dipengaruhi oleh faktor genetik dan lingkungan dalam dan luar kandungan, disamping itu juga dapat dimodifikasi oleh pengaruh sosial, ekonomi dan kultural. ${ }^{25}$

\section{KESIMPULAN DAN SARAN}

Berdasarkan hasil analisis dan pembahasan yang dikemukakan maka dapat disimpullkan bahwa:

1). Pemberian makanan pralaktasi bukan merupakan faktor risiko secara langsung terhadap kelangsungan hidup bayi.

2). Variabel umur dan sosial ekonomi mempunyai hubungan bermakna dengan kelangsungan hidup bayi. Variabel sosial ekonomi rendah merupakan faktor risiko terkuat penyebab rendahnya kelangsungan hidup bayi.Tingkat pendidikan ibu, tempat tinggal dan penolong persalinan tidak mempunyai hubungan bermakna dengan kelangsungan hidup bayi.

Dari kesimpulan yang disampaikan di atas, peneliti menyarankan: 1) Peningkatan pemantauan kunjungan neonatal khususnya pada ibu dengan sosial ekonomi rendah. 2) Sosialisasi bahwa menyusui adalah perilaku budaya tradisional tetapi memiliki keuntungan yang didukung oleh pengetahuan modern. 3) Perlu penelitian lebih lanjut mengenai kelangsungan hidup dengan menambahkan variabel pola pemberian $\mathrm{ASI}$, lama menyusui dan imunisasi serta variabel budaya dalam pemberian makanan pralaktasi.

\section{DAFTAR PUSTAKA}

1. Abidin Z. Perlindungan Anak dan Implementasinya. Tersedia dalam: http://www.kabarindonesia.com/ beritaprint.php. Diakses 2 Oktober 2009.

2. Black RE, Morris SS, Bryce J. Where and why are 10 million children dying every year? Lancet. 2003; (361): 2226-2234.

3. Badan Pusat Statistik, Macro International. Survei Demografi dan Kesehatan Indonesia 2007. Calverton, Maryland, USA: BPS dan Macro International; 2007.

4. Suhardjo. Pemberian makanan pada bayi dan anak. Yogyakarta: Kanisius; 1992.

5. Sastroasmoro S, Ismael S. Dasar-dasar metodologi penelitian klinis. Jakarta: Sagung Seto; 2008.

6. Hasan MI. Metodologi penelitian dan aplikasinya. Jakarta: Ghalia Indonesia; 2002.

7. Boedihardjo SD. Pemberian makanan untuk bayi, dasar-dasar fisiologis. Jakarta: Perinasia; 1994.

8. Suraatmaja S. Aspek gizi air susu ibu, dalam ASI petunjuk untuk tenaga kesehatan. Soetjiningsih, editor. Jakarta:EGC; 1997.

9. Edmond KM, Kirkwood BR, Tawiah CA, Agyei SO. Impact of early infant feeding practices on mortality in low birth weight infants from rural Ghana. Journal of perinatology. 2008; 28: 438-444. 
10. Ristrini, Budiarto W. Menyusui dan kelangsungan hidup anak. Majalah Demografi Indonesia. 1990; 17(34).

11. Butz WP, Vanzo DJ, Habicht JP. How biological and behavioral influence on mortality in Malaysia vary during the first year of life, population studies. $1982 ; 37$.

12. Nurmiati, Besral. Pengaruh durasi pemberian ASI terhadap ketahanan hidup bayi di Indonesia. Makara Kesehatan. 2008;12(2).

13. Moultan LH, Rahmathullah L, Halsey NA, Thulasiraj RD, Katz J, Tielsch JM. Evaluation of non-specific effect of infant immunizations on early infant mortality in a southern Indian population. Tropical Medicine and International Health. 2005; 10(10): 947-955.

14. Wilopo SA. Pola, trend dan perbedaan praktik menyusui di Indonesia: analisis deskriptif peran modernisasi dan budaya tradisional dari data Survey Demografi Kesehatan Indonesia. Jurnal Gizi Klinik Indonesia. 2007; 6(1): 42-51.

15. Nepal D, Sankar J, Misra S, Paul V. Determinant of early initiation of breastfeeding in a tertiary neonatal unit. J Pediatr. 2005; (29):2

16. Agnarsson I, Mpello A, Gunnlaugsson G, Hofvander $Y$, Greiner T. Infant feeding practice during the first six months of life in a rural area in Tanzania. Medical Journal. 2001;(78):1

17. Huyen T. Maternal education and place of residence in the timing of the initiation of breastfeeding in Vietnam. Chicago: Chicago University; 1998.

18. Kathleen, MM, Shankar RT. The practice of prelacteal feeding to newborns among hindu and muslim families. J.Midwifery Women's Health. 2009; 5(1):78-81.

19. Prakasam C.P. Influence of Mother age on child survival in Pakistan: Evidence from DHS data. 1990. Available from http://www.iassh.org/reach_ review/research/Pakistan_paper.pdf.

20. Buor D. Mother's education and childhood mortality in Ghana. Health Policy. 2001. (64):297309.
21. Bhuiya A, Streatfield K. Mother's education and survival of female children in a rural area of Bangladesh. Popul Stud. 1991; (45): 253-264.

22. Simbolon D. Kelangsungan hidup bayi di perkotaan dan pedesaan Indonesia. Jurnal Kesehatan Masyarakat Nasional. 2006; 1(1).

23. Ariawan I. Indeks sosio-ekonomi menggunakan Principal Component Analysis. Jurnal Kesehatan Masyarakat Nasional. 2006; 1(2): 83-87

24. Harto EP. Kematian Bayi di Kabupaten Purworejo Kajian dari Pemanfaatan Pelayanan Kesehatan dan Kondisi Sanitasi Lingkungan. Tesis. Yogyakarta: Program studi ilmu Kesehatan Masyarakat, Universitas Gadjah Mada. 2000.

25. Utomo B. Kematian bayi dan anak di Indonesia, beberapa implikasi kebijakan. Dalam: Singarimbun, M. Editor. Kelangsungan hidup anak. Yogyakarta: Gajah Mada University Press; 1988.

26. Winarno E. Mengkaji implementasi kebijakan lintas sektoral peningkatan kesejahteraan sosial masyarakat dalam upaya penurunan tingkat kematian bayi. Jurnal Penelitian Kesejahteraan Sosial, Balai Besar Penelitian Dan Pengembangan Pelayanan Kesejahteraan Sosial (B2P3KS), Yogyakarta. 2002.

27. Hong R, Beltran MR. Impact of prenatal care on infant survival in Bangladesh. J. Matern Child Health. 2007; (11);199-206.

28. Widayaton. Program penempatan bidan di desa di Indonesia dan tingkat pemanfaatan pelayanan kesehatan ibu dan anak : Bukan dukun atau dokter: tinjauan tentang program bidan di desa di Kawasan Timur Indonesia. Jakarta; 1999.

29. Hakimi M. Determinan pemilihan penolong dan tempat pertolongan persalinan di Kabupaten Purworejo. Laporan Penelitian. Yogyakarta: Laboratorium Penelitian Kesehataan dan Gizi Masyarakat FK UGM; 1999. 